International Journal of Environment, Agriculture and Biotechnology
Vol-6, Issue-6; Nov-Dec, 2021

\title{
Molecular Characterization of Bacterial that degrades herbicides isolated from soil environment in Abuja.
}

\author{
Owuna J.E ${ }^{1}$, Asa A.A. ${ }^{2}$, Ahmad A.A. ${ }^{1}$, Ibrahim Y. ${ }^{1}$, Haruna I.M. ${ }^{1}$ \\ ${ }^{1}$ Department of Microbiology, Nasarawa State University, Keffi, Nasarawa State, Nigeria. \\ ${ }^{2}$ National Root Crop Research Institute, Umudike, Abia State, Nigeria. \\ Corresponding Author: ojodoyin@gmail.com
}

Received: 01 Oct 2021; Received in revised form: 28 Nov 2021; Accepted: 05 Dec 2021; Available online: 12 Dec 2021

(C)2021 The Author(s). Published by Infogain Publication. This is an open access article under the CC BY license (https://creativecommons.org/licenses/by/4.0/).

\begin{abstract}
The study was aimed to determine the molecular characterization of bacterial that degrades herbicides isolated from soil environment in Abuja. The systemic chemical herbicide was applied on an experimental plot of land with weeds and its effects on soil bacteria and the physicochemical properties of the soil was examined for a period of seven weeks. The chemical herbicide, glyphosate, reduced the plate count of bacteria from $120 \times 10^{5} \mathrm{cfu} / \mathrm{g} / \mathrm{dwt}$ to $48 \times 10^{5} \mathrm{cfu} / \mathrm{g} / \mathrm{dwt}$ some hours after application and the reduction continued till the end of the sampling period. The isolated bacterial species were Simulium tani, Bacillus firmus, Pseudomonas tolaasii, Acinetobacter beijerinckii, Entrobacter sp, Citrobacter freundii, Pseudomonas poae. Organisms that were eliminated following glyphosate application were Bacillus magaterium, Pseudomonas tolaasii, Proteus $s p$, and Simulium tani while those that persisted throughout the experiment were Staphylococcus aureus, Pseudomonas poae, Bacillus firmus, and Entrobacter sp. It was concluded that glyphosate altered the microbial counts and had a temporary inhibitory effect on the type of bacteria present in the soil.
\end{abstract}

Keywords-degrades, herbicide, soil, isolated, microbial count.

\section{Introduction}

Herbicides are valuable tools for the selective control of un-desirable plants in crop production. However, various herbicides at recommended rates, whether applied to the foliage or soil, often persist in the soil for extended periods of time. These residues may cause serious damage to sensitive plant species grown the season(s) following application of the herbicides. The climatic and edaphic factors, e.g., temperature, moisture, $\mathrm{pH}$, soil composition, and cation exchange capacity which affect the residual life of herbicides, are numerous and complex.

Herbicides cause a range of health effects ranging from skin rashes to death. The pathway of attack can arise from intentional or unintentional direct consumption, improper Agricultural application resulting in the herbicide coming into direct contact with people or wildlife, inhalation of aerial sprays, or food consumption prior to the labeled preharvest interval.Pesticides can enter the human body through inhalation of aerosols, dust and vapour that contain pesticides, through oral exposure by consuming food and water, and through dermal exposure by direct contact of pesticides with the skin (Cooper and Dobson 2007).

Herbicide are often applied directly to soil. They may also reach the soil through application to foliage via spray drift, run-off, or wash-off vectors. Once released to the environment, chemicals undergo various dissipation pathways, and the persistence of chemicals in the environment varies widely. Among factors affecting the local concentration of a compound are the amount of compound released, the rate of compound released, its persistence in the environment under various conditions, the extent of its dilution, its mobility, and the rate of biological or non-biological degradation (Ellis 2000 and Janssen et al. 2001).

Herbicide biodegradation involves a wide variety of microorganisms including bacteria and fungi operating under dynamic anaerobic and aerobic conditions. It is suggested that biodegradation of pesticides in soil ecosystems can only take place through the synergistic 
interactions of a microbial consortium, the activity of which is affected by many soil physical and chemical properties, as well as the nature and extent of the pesticide contamination.

Soil microbes make valuable contribution to soil fertility. Pesticides can exhibit, stimulate and neutral effect on soil microbes, depending on the nature and concentrations as well as strain or types of microbes (Busseet al., 2001).

Herbicides will remain toxic in soil when conditions are not favorable for microbes. Degradation of the herbicide follows the population growth of the microbes. During the lag phase the microbial population increases in response to food source and rapid decomposition occurs. (Busse et al., 2001).

It drastically reduces the microbial population when applied to any soil sample. Synthetic herbicides have the potential to influence plant disease by several mechanisms. They can enhance disease or protect plants from pathogens due to direct effects on the microbe, to effects on the plant, or to effects on both organisms.

\section{MATERIALS AND METHOD}

\section{Collection of soil samples}

Soil samples were collected from the research farm of National Root Crop Research Institute, Nyanya Out Station, Abuja, Nigeria (Latitude $9.0765 \mathrm{~N}$ and Longtitude 7.3986E).

Soil samples were taken randomly with soil anger from each of the experimental plots and control plot, top soils of $0-15 \mathrm{~cm}$ depth were used. Cassava and Maize arethecrops grown in the farm. These crops have been sprayed with glyphosate organophosphorusherbicide for the last 45years. Plots of land measuring $3 \times 3 \mathrm{~m}$ with four replicates arranged in randomized form was used for the experiment.Samples were collected before and after application of herbicide on from week one to the seventh week. Soil samples were sieved with $2.0 \mathrm{~mm}$ mesh to remove stones and plant debris in soil. Samples were taken immediately to the laboratory into sampling bags for immediate analysis. (Makut and Ifeanyi 2017).

The herbicide, Glyphosate, was dissolved in distilled water at recommended rate of $50 \mathrm{ml}$ to five liter of water was used in this study, the mixture was then applied to the experimental plots and distil water was added to the control plots for comparison.

Isolation of Bacteria from soil contaminated with herbicide.
One (1.0) gram of the soil sample was weighed using weighing balance suspended in $9 \mathrm{ml}$ of sterile water. It was properly mixed and a 10 -fold serial dilution was carried out into seven dilutions.

The identification and characterization of bacterial isolates were based on cultural, morphological and biochemical characteristic using standing method. (Mendes et al., 2017).

\section{Molecular Identification of Bacteria isolated from herbicide contaminated soil.}

The molecular identification of bacteria isolated from herbicide contaminated soil where carried out using Bacterial genomic DNA extraction, DNA quantification, 16SrRNA Amplification and Sequencing.

\section{Determining the effects of Temperature, pH and Days} on biodegradation of herbicides

Biodegradation experiment was carried out at two different temperatures $\mathrm{pH}$ and weeks (herbicides $3.0 \mathrm{mg} / \mathrm{ml}$ ) using the methods of Thavasi et al., (2007).

Experiment to determine the effect of temperature on herbicides biodegradation by bacteria was carried out at various temperature for 15 days.

The effect of $\mathrm{pH}$ on biodegrading potential of bacteria was determined by adjusting the $\mathrm{pH}$ between $\mathrm{pH} 4.5$ and $\mathrm{pH} 8.5$ and were incubated for 15 days.

Effect of Days on herbicides biodegradation was carried out by incubating for different weeks ranging from 1- 7 weeks.(Jurado, et al, 2011).

\section{Quantification of Pesticide Residue}

This was carried out using Gas chromatography spectrophotometer on the biodegraded sample. The aqueous samples were analyzed by directly derivatizing an aliquot and the derivatizing reagent mixture was prepared fresh by mixing one volume of Heptafluoro-butanol to two volumes of Trifluroacetic Anhydride.

\section{RESULT AND DISCUSSION}

The herbicide treatment used was observed to have negative effect on the microbial load. In glyphosate treated soil, there was a gradual decrease in bacterial population, that is, from $120 \times 10^{6} \mathrm{cfu}$ first day after application to 101 $\mathrm{x} 10^{6} \mathrm{cfu}$ after one week of application. But by the third week of application, there was a sharp decrease of $77 \mathrm{x}$ $10^{6} \mathrm{cfu}$ to $48 \times 10^{6} \mathrm{cfu}$ by the sixth week of application. The bacteria count from contaminated and non-contaminated soil is as given in Table 1.

Table 1: Total Bacteria Counts for Bacteria10 $0^{6}$ (cfu) $/ g$ / $d w t$. 


\begin{tabular}{|c|c|c|c|c|c|c|c|}
\hline SAMPLE & $\begin{array}{l}\text { TIME } \\
\text { SAMPLING }\end{array}$ & TBC & & $\begin{array}{l}\text { sampl } \\
\text { ed }\end{array}$ & No. $(\%)$ & $\begin{array}{l}\text { No. } \\
(\%)\end{array}$ & No. (\%) \\
\hline ES1 & \multirow{2}{*}{$\begin{array}{l}\text { Immediately } \\
\text { herbicide } \\
\text { application }\end{array}$} & \multirow[t]{2}{*}{120} & $\begin{array}{l}\text { Pseudomonas } \\
\text { poae }\end{array}$ & 5 & $0(0.0)$ & $0(0.0)$ & $2(40.0)$ \\
\hline CS1 & & & $\begin{array}{l}\text { Pseudomonas } \\
\text { tolaasii }\end{array}$ & 5 & 1(20.0) & $0(0.0)$ & $0(0.0)$ \\
\hline \multirow[t]{2}{*}{ ES2 } & \multirow{3}{*}{$\begin{array}{l}\text { A week } \\
\text { herbicide } \\
\text { application }\end{array}$} & 101 & Proteus sp & 5 & $0(40.0)$ & $1(60.0)$ & $0(0.0)$ \\
\hline & & & Priestia flexa & 5 & $0(0.0)$ & $1(20.0)$ & $0(0.0)$ \\
\hline $\mathrm{CS} 2$ & & 115 & $\begin{array}{l}\text { Bacillus } \\
\text { firmus }\end{array}$ & 5 & $0(0.0)$ & $0(0.0)$ & $1(20.0)$ \\
\hline ES3 & $\begin{array}{l}\text { Two weeks after } \\
\text { application }\end{array}$ & 70 & $\begin{array}{l}\text { Bacillus } \\
\text { magaterium }\end{array}$ & 5 & $1(20.0)$ & $1(20.0)$ & $0(0.0)$ \\
\hline CS3 & & 110 & Simulium tani & 5 & $0(0.0)$ & $1(20.0)$ & $0(0.0)$ \\
\hline ES4 & $\begin{array}{l}\text { Three weeks after } \\
\text { application }\end{array}$ & 75 & $\begin{array}{l}\text { Acinetobacter } \\
\text { beijerinckii }\end{array}$ & 5 & $0(0.0)$ & $0(0.0)$ & $1(20.0)$ \\
\hline CS4 & & 118 & Citrobacter & 5 & $0(0.0)$ & $0(.0)$ & $1(20.0)$ \\
\hline ES5 & Four weeks after & 55 & freundii & & & & \\
\hline
\end{tabular}

CS5 application

The screening for survival of different bacteria in herbicides broth is as given in Table 3 . The ability of the bacteria isolated from contaminated soil with herbicides showed that Pseudomonas tolaasii, Pseudomonas poae, Proteus sp, Priestia flexa, Bacillus magaterium, Bacillus firmus, Simulium tani, Acinetobacter beijerinckii and Citrobacter freundii were able to survival in herbicide concentration broth.

Table 3: Screening for Survival in Herbicides Broth

KEYS:

ES: Experimental Sample

CS: Control of Experimental Sample

TBC: Total Bacteria Count

Pseudomonas poae isolated from contaminated soil had percentage occurrence of $40.0 \%$ from Plot C and Pseudomonas tolaasii had $20.0 \%$ from plot A. Proteussp had $60.0 \%$ occurrence from plot B, Priestiaflexa had $20.0 \%$ occurrence from plot B, Bacillus firmus had $20.0 \%$ occurrence from plot $\mathrm{C}$, similarly Bacillusmagaterium had $20.0 \%$ occurrence from plot A and B respectively, Simuliumtani had $20.0 \%$ occurrence from plot B, Acinetobacter beijerinckiiand Citrobacter freundii had $20.0 \%$ occurrence from plot $\mathrm{C}$ respectively, Table 2.

Table 2: Percentage Occurrence of different Bacteria from Contaminated Soil with Herbicide

\begin{tabular}{lll}
\hline Bacteria & Lab code & Utilization \\
\hline Pseudomonas tolaasii & Plot A 1a & + \\
Pseudomonas poae & Plot C 2b & + \\
Pseudomonas sp & Plot C 4a & - \\
Proteus sp & Plot A 1b & - \\
Proteus sp & Plot A 2a & - \\
Proteus sp & Plot B 5a & + \\
Priestia flexa & Plot A 3c & + \\
Bacillus magaterium & Plot B 4a & + \\
Bacillus sp & Plot B 5a & - \\
Bacillus firmus & Plot C 3c & + \\
Simulium tani & Plot B 2a & + \\
Acinetobacter beijerinckii & Plot C 4b & + \\
Entrobactersp & Plot A 5c & - \\
Citrobacter freundii & Plot C 1c & + \\
\hline
\end{tabular}


The effect of temperature on utilization of herbicide is as shown in Table 4. Pseudomonas tolaasii had the highest utilization at $35^{\circ} \mathrm{C}(2.19 \pm 0.26 \mathrm{mg} / \mathrm{ml})$ followed by $30^{\circ} \mathrm{C}$
$(2.06 \pm 0.64 \mathrm{mg} / \mathrm{ml})$ and least was at $26^{\circ} \mathrm{C}$ $(1.23 \pm 01.1 \mathrm{mg} / \mathrm{ml})$.

Table 4: Effect of temperature on utilization of herbicides by different bacteria.

\begin{tabular}{lllll}
\hline \multicolumn{2}{l}{ Herbicide Conc. $(\mathbf{m g} / \mathbf{m l})$} & Temperature $\left({ }^{\circ} \mathbf{C}\right)$ & $\mathbf{3 5}$ \\
Isolates & & $\mathbf{2 6}$ & $\mathbf{3 0}$ & $2.19 \pm 0.26$ \\
\hline Pseudomonas tolaasii & 5 & $1.23 \pm 01.1$ & $2.06 \pm 0.64$ & $2.15 \pm 0.08$ \\
Pseudomonas poae & 5 & $1.14 \pm 0.29$ & $2.01 \pm 0.23$ & $1.92 \pm 0.16$ \\
Proteussp & 5 & $0.53 \pm 0.86$ & $1.97 \pm 0.05$ & $1.94 \pm 0.34$ \\
Priestiaflexa & 5 & $1.55 \pm 0.15$ & $2.12 \pm 0.19$ & $1.80 \pm 0.05$ \\
Bacillus magaterium & 5 & $1.48 \pm 0.24$ & $2.00 \pm 0.03$ & $1.62 \pm 0.08$ \\
Bacillus firmus & 5 & $1.02 \pm 0.86$ & $2.02 \pm 0.57$ & $2.07 \pm 0.24$ \\
Simuliumtani & 5 & $1.12 \pm 0.82$ & $1.48 \pm 0.10$ & $1.27 \pm 0.35$ \\
Acinetobacter beijerinckii & 5 & $1.17 \pm 0.35$ & $1.86 \pm 0.28$ & $1.97 \pm 0.05$ \\
Citrobacter freundii & 5 & $1.45 \pm 0.17$ & $1.47 \pm 0.15$ & \\
\hline
\end{tabular}

The effect of $\mathrm{pH}$ on herbicide utilization by bacteria isolates is as shown table 5. Pseudomonas tolaasii had the highest utilization at $\mathrm{pH} 7.0(3.5 \pm 0.3 \mathrm{mg} / \mathrm{ml})$ followed by $\mathrm{pH} 6.5(3.1 \pm 0.3 \mathrm{mg} / \mathrm{ml}), \mathrm{pH} 6.0(2.1 \pm 0.1 \mathrm{mg} / \mathrm{ml})$ and the least was $\mathrm{pH} 5.5$ $(1.7 \pm 0.3 \mathrm{mg} / \mathrm{ml})$.

Table 5: Effect of pH on herbicide utilization by different bacteria isolates

\begin{tabular}{|c|c|c|c|c|c|}
\hline \multirow[b]{2}{*}{ Isolates } & \multirow{2}{*}{$\begin{array}{l}\text { Herbicide Conc. } \\
(\mathrm{mg} / \mathrm{ml})\end{array}$} & \multicolumn{4}{|c|}{ Degree of Acidity and Alkaline (pH) } \\
\hline & & 5.5 & 6.0 & 6.5 & 7.0 \\
\hline Pseudomonas tolaasii & 5 & $1.7 \pm 0.3$ & $2.1 \pm 0.1$ & $3.1 \pm 0.3$ & $3.5 \pm 0.3$ \\
\hline Pseudomonas poae & 5 & $2.0 \pm 0.1$ & $1.9 \pm 0.8$ & $2.1 \pm 0.3$ & $2.8 \pm 0.8$ \\
\hline Proteus sp & 5 & $1.7 \pm 0.1$ & $1.8 \pm 0.2$ & $1.9 \pm 0.1$ & $2.1 \pm 0.1$ \\
\hline Priestia flexa & 5 & $2.1 \pm 0.1$ & $2.8 \pm 0.2$ & $3.1 \pm 0.2$ & $3.3 \pm 0.1$ \\
\hline Bacillus magaterium & 5 & $2.8 \pm 0.1$ & $3.0 \pm 0.8$ & $3.0 \pm 0.6$ & $3.6 \pm 0.5$ \\
\hline Bacillus firmus & 5 & $2.3 \pm 0.2$ & $2.6 \pm 0.1$ & $2.8 \pm 0.2$ & $2.8 \pm 0.3$ \\
\hline Simulium tani & 5 & $2.6 \pm 0.8$ & $2.8 \pm 0.1$ & $2.8 \pm 0.2$ & $3.0 \pm 0.1$ \\
\hline Acinetobacter beijerinckii & 5 & $1.7 \pm 0.2$ & $1.8 \pm 0.2$ & $2.0 \pm 0.5$ & $2.6 \pm 0.1$ \\
\hline Citrobacter freundii & 5 & $1.6 \pm 0.1$ & $1.8 \pm 0.2$ & $2.0 \pm 0.5$ & $2.8 \pm 0.2$ \\
\hline
\end{tabular}

DNA sequence analysis/molecular identification of microbes

Blast analysis of the gene sequence of the pure bacteria culture identified three bacteria species of the genus Pseudomonas, Priestia and Bacillus, of which Pseudomonas dominated the samples, Table 6.

The relatively high abundance of Pseudomonas species in the samples might be due to their high ability to tolerate and degrade pesticides (Darsaet,al. 2014). Similar studies have been conducted by Asef 2014 and have documented the isolation, molecular characterization and pesticide degradation by Aspergillus species. Therefore, the presence of these bacterial species in our study can suggest their biodegradation potential towards pesticide. 


International Journal of Environment, Agriculture and Biotechnology
Vol-6, Issue-6; Nov-Dec, 2021
J Journal Home Page Available: https://ijeab.com/
Journal DOI: $10.22161 /$ ijeab

Table 6: Molecular Characterization of Bacterial Isolates

\begin{tabular}{|c|c|c|c|}
\hline Sample ID & Organism Identified by BLAST & Identity (\%) & Sequence Length (Bp) \\
\hline Plot A 1a & $\begin{array}{l}\text { Pseudomonas tolaasii strain Pt11 } \\
\text { Pseudomonas sp. bs } 2935 \\
\text { Pseudomonas sp. MYb193 } \\
\text { Pseudomonas libanensisstrain DMSP-1 }\end{array}$ & 88 & 6475196 \\
\hline Plot C 2b & $\begin{array}{l}\text { Pseudomonas poae strain PMA22 } \\
\text { Pseudomonas antarctica strain BS2772 } \\
\text { Pseudomonas sp. ADAK22 } \\
\text { Pseudomonas lurida strain MYb11 }\end{array}$ & 90 & 6530734 \\
\hline Plot B 4a & $\begin{array}{l}\text { Bacillus magaterium strain PHB06 } \\
\text { Bacillus } s p \text {. strain magaterium-M1 } \\
\text { Bacillus } s p \text {. strain AM136 } \\
\text { Priestia magaterium strain R2A90 }\end{array}$ & 100 & 1493 \\
\hline Plot A 3c & $\begin{array}{l}\text { Priestia flexa } \text { strain } \mathrm{QG}-3 \\
\text { Priestia flexa } \text { strain } \mathrm{TH} 25 \\
\text { Priestia flexa } \text { strain FYF01 } \\
\text { Priestia flexa } \text { strain BUMD13 }\end{array}$ & 100 & 1515 \\
\hline Plot C 3c & $\begin{array}{l}\text { Bacillus firmus } \\
\text { Bacillus sp mixed culture X3-37 } \\
\text { Bacillus sp Al-Dhabi-17 BAU } \\
\text { Bacillus sp strain 35-Lb11/2 }\end{array}$ & 95 & 1359 \\
\hline Plot B 2a & $\begin{array}{l}\text { Simulium tani } \\
\text { Uncultured bacterium clone MSD18_A02 } \\
\text { Bacillus sp. mixed culture X3-37 } \\
\text { Bacillus sp. Al-Dhabi-17 }\end{array}$ & 100 & 1420 \\
\hline Plot C 4b & $\begin{array}{l}\text { Acinetobacter beijerinckii strain LMA2 } \\
\text { Uncultured Priestia sp clone RJCEP_01 } \\
\text { Priestia aryabhattai strain MSAR20 } \\
\text { Uncultured actinobacterium clone STJ C42 }\end{array}$ & 88 & 786 \\
\hline Plot C 1c & $\begin{array}{l}\text { Citrobacter freundii strain RHBSTW } \\
\text { Enterobacter sp. RHBSTW-00975 } \\
\text { Enterobacterasburiae MRY18-106 } \\
\text { Enterobacter sp. HP19 }\end{array}$ & 100 & 109959 \\
\hline
\end{tabular}

Phylogenetic analysis

The Phylogenetic analysis revealed that the soil contained diverse bacterial clustering into three orthologous groups. Reason maybe the combination of selective factors, 
proximity and functional capacity of microbes. Functionally, phylogenetically distant lineages can share common functional features and functions (Ning and Beiko 2015). Ning and Beiko 2015 also opined that functional similarities exist between operational taxonomic units (OTUs) that belong to different high-level taxonomic groups. Most of microbial sequences analyzed in different taxonomic divisions could be related to representatives with known metabolic traits.

\section{Correlation between different parameters}

Some correlations were also calculated from the results, at the end of the experiment when the organisms were suggested to be highly metabolic active. The negative correlation observed between pesticide degradation and colony count suggests the negative impact pollutants may have on biodiversity. These relationships would be useful to biodegradation of glyphosate and other organic contaminants in the environment (Showunmiet,al. 2020).

\section{CONCLUSION}

From the findings of this study, it suggests that the organisms isolated and identified have the potential to degrade glyphosate pollutants when applied in the environmentally friendly technology clean-up (bioremediation) of glyphosate contaminated environment. Therefore factors promoting their growth should be encouraged.

Herbicides are phytotoxic chemicals used for destroying various weeds or inhibiting their growth. It is important to also know that excess use of herbicides in agroecosystems may change composition of weed populations and diversity.

Excess use of herbicide should be minimize in wildlands, as herbicides may increase the diversity of native species. Threats to plant biodiversity caused by habitat loss and invasive species are far greater than threats by use of herbicides.

It is also important to properly managed lands that are spread with herbicide as spray runoff in sandy soils may cause tree injury if followed soon after with irrigation or rainfall.

To prevent contamination of water bodies, management plans should carefully consider the hydrology of the system that is being treated. Hypothesize potential runoff scenarios and take appropriate measures (such as buffer zones) to prevent them. Underground aquifers and streams should be considered as well.
[1] Asef, I. M. Isolation of pesticide degrading microorganisms from soil. Advances in Bioresearch 2014: 5(4): 164-168.

[2] Busse, M.D., Ratcliff, A.W., Stestak, C.J., Powers, R.F. (2001). Glyphosate toxicity and the effects of long term vegetation control on soil microbial communities. Soil Biol. And Biochemistry J. Vol.33:1777-1789.

[3] Cooper, J. and Dobson, H. 2007. The benefits of pesticides to mankind and the environment. Crop Protection 26(9): 1337-1348

[4] Darsa, K., Thatheyus, J. and Ramya, D. 2014. Biodegradation of petroleum compound using the bacterium bacillus subtilis. Science International. 2014: 2: 20-25.

[5] Ellis, F. (2000). The determinants of rural livelihood diversification in developing countries. J. Agricultural Economis. 51, 289-302.

[6] Janssen, M.A. (2007). An update on the scholarly networks on Resilence, Vulnerability and Adaptation within the human dimentions of global environmental change. J. Ecology and Society. 12(2):9-15.

[7] Jurado, A.S., Fernandes, M.A.S., Videira, R.A., Peixoto, F.P., Vicente, J.A.F. (2011).Herbicides: The Face and the Reverse of the Coin. An in vitro Approach to the Toxicity of Herbicides in Non-Target Organisms. In: KORTEKAMP, A. (Ed.) Herbicides and Environment. Kroatia, 3- 45.

[8] Makut M.D. and Ifeanyi U. E. (2017). Screening for citric acid producing fungi from the soil Environment of Jos North, Plateau State, Nigeria.FULafia Journal of Science \& Technology. 3 (1):1-12

[9] Mendes, K.F., Freguglia, R.M.O., Martins, B.A.B, Dias R.C., PimpinatoR.FandTornisielo V.L (2017). Cow bonechar for pesticide removal from drinking water. Scholars Journal of Agriculture and Veterinary Sciences. 4:504-512.

[10] Ning, J. and Beiko, G. 2015. Phylogenetic approaches to microbial community classification. Microbiome 2015: 3(1 ): 47-49.

[11] Sowunmi, K. Shoga, S.M. Adewunmi, O.M. Oriyomi, A.F. Sowunmi, L. 2020. Isolation and Molecular Characterization of Pesticide Degrading Bacteria in Polluted Soil. doi: https://doi.org/10.1101/2020.07.21.213942.

[12] Thavasi, R., Jayalakshmi, S., Balasubramanian T., Banat, I.M. (2007). Effect of salinity, temperature, $\mathrm{pH}$ and crude oil concentration on biodegradation of crude oil by Pesudomonas aeruginosa. Retrieved from www.acikenisim.uludag.edu.tr on Jan 12, 2021.

\section{REFERENCES}

